\title{
OPTIMIZATION OF MOOSEER (A. HIRTIFOLIUM BOISS.) DEHYDRATION UNDER INFRARED CONDITIONS
}

\author{
Reza Amiri Chayjan ${ }^{\bowtie}$, Mosayeb Fealekari \\ Department of Biosystems Engineering, Faculty of Agriculture, Bu-Ali Sina University \\ 6517833131, Hamedan, Iran
}

\begin{abstract}
Background. In recent years, infrared drying has gained popularity as an alternative drying method for a variety of agricultural products. The use of infrared radiation technology in drying agricultural products has several advantages. These may include decreased drying time, high energy efficiency, high-quality finished products and uniform temperature in the product. With intermittent infrared and convection heating of a thick porous material, the drying time can be reduced compared to convection alone, while keeping good food quality and high energy efficiency.

Material and methods. Response surface methodology $(R S M)$ was employed to optimize the drying conditions of mooseer under infrared-convective drying. Experiments were performed at air temperatures of 40,55 and $70^{\circ} \mathrm{C}$, infrared powers of 500,1000 and $1500 \mathrm{~W}$, air velocities of $0.5,1.5$ and $2.5 \mathrm{~m} / \mathrm{s}$ and slice thicknesses of 2, 4, and $6 \mathrm{~mm}$. In this study, effective moisture diffusivity $\left(D_{\text {eff }}\right)$, shrinkage, color changes and specific energy consumption $(S E C)$ were investigated. The central composite design $(C C D)$ was selected for the design and optimization of the process.

Results. $D_{\text {eff }}$ was obtained between $1.4 \times 10^{-10}$ and $3.57 \times 10^{-9} \mathrm{~m}^{2} / \mathrm{s}$. With increasing air temperature and slice thickness, $D_{\text {eff }}$ also increased. The level of shrinkage rose as slice thickness increased. The highest and lowest values of color changes were calculated at air temperatures of $70^{\circ} \mathrm{C}(52.3 \%)$ and $40^{\circ} \mathrm{C}(5.65 \%)$, respectively. Increasing air velocity led to an increase in SEC.

Conclusion. Optimum conditions for mooseer drying were achieved at air temperature of $70^{\circ} \mathrm{C}$, infrared power of 867.46 , air velocity of $0.59 \mathrm{~m} / \mathrm{s}$ and slice thickness of $2 \mathrm{~mm}$. At this point, $D_{\text {eff }}$, shrinkage, color changes and SEC was obtained as $1.32 \times 10^{-9} \mathrm{~m}^{2} / \mathrm{s}, 29.58 \%, 17.62 \%$ and $4.64 \mathrm{MJ} / \mathrm{kg}$, respectively. The desirability value of 0.689 was achieved for the drying process.
\end{abstract}

Keywords: infrared, color changes, response surface, mooseer, optimization, shrinkage

\section{INTRODUCTION}

Mooseer (A. hirtifolium Boiss.), which is native to Iran, is a type of shallot. It grows as a wild plant in the Zagross Mountains in the western, southern and central parts of Iran (Ebrahimi et al., 2009). It is a wild, perennial, herbaceous and aromatic plant. It consists of a naked and erect scape with a height of 80 to $120 \mathrm{~cm}$.
Its green leaves are linear and lanceolate, ranging from 20 to $30 \mathrm{~cm}$ length (Ghahreman, 1984).

It is believed alliums can treat diabetes, arthritis, colds and flu, stress, fever, coughs, headache, hemorrhoids, asthma, arteriosclerosis, cancer, rheumatic and inflammatory disorders (Eidi et al., 2006). 
Drying is the most common form of food preservation. This process improves food stability, since it reduces considerably the water and microbiological activity of the material and minimizes physical and chemical changes during its storage. Drying is the most energy intensive process in the food industry. Therefore, new drying techniques and dryers must be designed and studied to minimize the energy cost in the drying process (Doymaz, 2011).

Because of the low thermal conductivity of food materials, heat transfer to the inner sections of food during conventional heating is limited. During drying, the product's quality characteristics change in considerable ratios because of the heat treatment applied and sometimes these changes are not desirable. Furthermore, drying is an energy-intensive process, since its energy consumption value is $10-15 \%$ of the total energy consumption in all industries in developed countries (Erbay and Icier, 2010). The need to eliminate this problem, prevent significant quality loss and achieve fast and effective thermal processing has resulted in the increasing use of infrared and microwaves for food drying (Togrul, 2005). Rising demand for high-quality shelf-stable dried vegetables requires the design, simulation and further optimization of the drying process with the purpose of accomplishing not only the efficiency of the process but also the final quality of the dry product (Arslan and Özcan, 2011).

Modeling and optimization to increase the efficiency of the process is one of the most important stages in a thermal process. The relationship between interfering factors and final outputs has great value for researchers. However, many numerical methods have major drawbacks in finding constants and solving the complexities of non-linear behaviors (Abbasi Surki et al., 2010).

Optimization has been applied in food process engineering for the efficient operation of systems and unit processes yielding a high-quality product (Corzo et al., 2008). Modeling and optimizing the process is vital in drying technology to increase the efficiency of the drying facilities. Complex and highly nonlinear phenomena are involved in the drying process (Omid et al., 2009).

Response surface methodology (RSM) is a mathematical/statistical based technique which is useful for analyzing the effects of several independent variables on the response (Amouzgar et al., 2010). The RSM is a powerful optimum design tool in many engineering applications. It can not only save a lot of time but also build models quickly and accurately in an optimized design (Nazghelichi et al., 2011).

Response surface methodology (RSM) is one of the most commonly used optimization techniques in food science, probably because of its comprehensive theory, high efficiency and simplicity (Amouzgar et al., 2010; Erbay and Icier, 2010; Eren and Kaymak-Ertekin, 2007; Kiat Pua et al., 2010; Nazghelichi et al., 2011; Sharma and Prasad, 2006; Varnalis et al., 2004; Wani et al., 2008).

There is no information available about the physical and thermal properties of mooseer and optimization of its drying process in the literature. The aims of this study were therefore: (a) to determine of some physical and thermal properties of mooseer in an infrared-convective dryer, (b) to study the effect of independent variables on the dependent variables and (c) to optimize mooseer drying in an infrared-convective dryer.

\section{MATERIAL AND METHODS}

The samples of mooseer were collected from agricultural lands in Songhor, Kermanshah province, Iran. They were stored in a refrigerator at $3 \pm 1^{\circ} \mathrm{C}$. A standard hot air oven method (ASAE, 1996) was used to determine the moisture content of the samples in triplicate. The average moisture content of the samples was 1.99 (d.b.).

The samples of mooseer were dried in a laboratory infrared-convective dryer. The relative humidity and temperature of ambient air during the experiments were recorded at the range of $18-26 \%$ and $23-28^{\circ} \mathrm{C}$, respectively. Four parameters: air temperature, infrared power, air velocity and slice thickness were selected as input variables. Three levels of air temperature $\left(40,55\right.$ and $\left.70^{\circ} \mathrm{C}\right)$, infrared power $(500,1000$ and $1500 \mathrm{~W})$, air velocity $(0.5,1.5$ and $2.5 \mathrm{~m} / \mathrm{s})$ and slice thickness $(2,4$ and $6 \mathrm{~mm})$ were applied in the drying experiments. All experiments were performed in three replications. The air flow in the drying chamber was perpendicular to the sample surface. Before starting the experiment, the mooseer bulbs were sliced manually to create samples with a diameter of $10 \mathrm{~mm}$ and 
different thickness $(2,4$ and $6 \mathrm{~mm})$. After the dryer condition had reached a steady state for operation velocity, infrared power and temperature, the samples were put in the drying chamber and the drying process was started.

The response surface method was used to study the effects of air temperature, infrared power, air velocity and slice thickness on the dependent variables (effective moisture diffusivity, shrinkage, color changes and specific energy consumption). The experiments were based on a face-centered central composite design $(C C D)$. In this experimental design, three coded levels for each variable were selected: $-1,0$ and +1 corresponded to the low level, medium level and high level of each independent variable, respectively. The independent variables and representative coded and un-coded levels are given in Table 1.

Table 1. The independent variables and representative coded and un-coded levels

\begin{tabular}{lcrcc}
\hline \multirow{2}{*}{$\begin{array}{c}\text { Independent } \\
\text { variables }\end{array}$} & Symbol & \multicolumn{4}{c}{ Coded values } \\
\cline { 3 - 5 } Air temperature & $X_{1}$ & 40 & 55 & 70 \\
Infrared power & $X_{2}$ & 500 & 1000 & 1500 \\
Air velocity & $X_{3}$ & 0.5 & 1.5 & 2.5 \\
Slice thickness & $X_{4}$ & 2 & 4 & 6 \\
\hline
\end{tabular}

The behavior of the response surface was studied for the response function $(y)$ using the polynomial regression equation. The generalized response surface model is given as follow:

where:

$$
\mathrm{y}=\beta_{o}+\sum_{j=1}^{k} \beta_{o} x_{j} \sum i \prec j \sum \beta_{i j} x_{i} x_{j}+\sum_{j=1}^{k} \beta_{j j} x_{j}^{2}
$$

$y$ - the response calculated by the model,

$b_{o}-\mathrm{a}$ constant,

$b_{j}, b_{i j}, b_{i j}$ - linear, squared and interaction coefficient, respectively.

All experiments were conducted in a random order. To calculate the sum of square error and the lack of fitness for the developed regression equation between the dependent and independent variables, six replications were performed at the central points of the coded variables. Design Expert software (Version 7) was used for experimental design matrix, data analysis, graphical analysis and optimization procedure. RSM was chosen as the method for the software to calculate the optimum value in the software. The first step in $R S M$ is to find a suitable approximation for the true functional relationship between the response and the set of independent variables (Montgomery, 2001). A total of 30 experiments were specified by the software and conducted in an infrared-convective dryer.

Moisture diffusivity is a transport property related to a solid's drying or rehydration phenomena. Its accurate prediction can lead to the optimization of the drying process (Jain and Pathare, 2007). It has been accepted that the mass transfer of biological products in the falling rate period can be described by using Fick's second law in diffusion mode (Arslan and Özcan, 2011).

To determine effective moisture diffusivity $\left(D_{\text {eff }}\right)$ the eq. (2) (for an infinite slab) can be defined as follows (Crank, 1975):

$$
\begin{aligned}
M R & =\frac{M-M_{e}}{M_{0}-M_{e}}= \\
& =\frac{8}{\pi^{2}} \sum_{n=1}^{\infty} \frac{1}{(2 n+1)^{2}} \exp \left(-\frac{(2 n+1)^{2} \pi^{2} D_{\mathrm{eff}} t}{4 h^{2}}\right)
\end{aligned}
$$

where:

$M R$ - the dimensionless moisture ratio,

$M$ - the moisture content at any time, \% d.b.,

$M_{e}$ - the equilibrium moisture content, \% d.b.,

$M_{0}^{e}$ - the initial moisture content, \% d.b.,

$h$ - the half thickness of the slab in sample, $\mathrm{m}$,

$t$ - the drying time, $\mathrm{s}$,

$D_{\text {eff }}$ - the effective moisture diffusivity, $\mathrm{m}^{2} / \mathrm{s}$.

Moisture ratio $(M R)$ can be simplified to $M / M_{0}$ because $M_{e}$ was relatively small compared to $M$ and $M_{0}$. Equation (2) can be written as a logarithmic form:

$$
\ln (M R)=\ln \left(\frac{8}{\pi^{2}}\right)-\left(\frac{\pi^{2} D_{\text {eff }} t^{2}}{4 h^{2}}\right)
$$


The slope $\left(K_{0}\right)$ is calculated by plotting $t$ against $\ln (M R)$ as follows:

$$
K_{0}=\frac{\pi^{2} D_{\text {eff }}}{4 h^{2}}
$$

Decreasing the moisture content during drying was found to produce a non-isotropic change in the volume of the sample, which is expressed as shrinkage. This shrinkage occurs during the dehydration of fruits and vegetables when the viscoelastic matrix contracts into the space previously occupied by the water removed from the cells. Shrinkage is measured directly with a caliper or micrometer or indirectly by measuring changes in related parameters such as thickness, area, perimeter, porosity and density (Ebrahimi et al., 2012). In this study, the volume of the sample was measured by digital caliper with an accuracy of 0.01 $\mathrm{mm}$. Shrinkage is calculated using the following equation (Mayor and Sereno, 2004):

where:

$$
S_{b}=\frac{\left(V_{0}-V\right)}{V_{0}} \cdot 100
$$

$S_{b}$ - shrinkage, $\%$,

$V_{0}, V$ - the volume of sample before and after drying, respectively, $\mathrm{m}^{3}$.

Color is considered a fundamental physical property of agriculture products and foods, since it has been widely demonstrated that it correlates well with other physical, chemical and sensorial indicators of product quality. In fact, color plays a major role in the assessment of external quality in the food industries and food engineering research (Mendoza et al., 2006). The color change $(\triangle R G B)$ in the mooseer samples was measured by a color analyzer RGB-1002 (made in Taiwan) before and after drying. First, the color analyzer was calibrated using a standard calibration plate with a white surface for $R$ (red), $G$ (green) and $B$ (blue). The percent of the color change was determined using the gray level at the end of the process. Color change in $\triangle R G B$ is achieved using the following equations:

$$
\begin{aligned}
& \Delta R=\frac{R_{1}-R_{2}}{R_{1}} \cdot 100 \\
& \Delta G=\frac{G_{1}-G_{2}}{G_{1}} \cdot 100
\end{aligned}
$$

$$
\begin{aligned}
& \Delta B=\frac{B_{1}-B_{2}}{B_{1}} \cdot 100 \\
& G L=\frac{\Delta R+\Delta G+\Delta B}{3}
\end{aligned}
$$

where:

$\Delta R$ - the percentage change in red $R_{1}$ and $R_{2}$ the red color before and after drying, respectively,

$\Delta G$ - the percentage change in green $G_{1}$ and $G_{2}$ are the green color before and after drying, respectively,

$\Delta B$ - the percentage change in blue, $B_{1}$ and $B_{2}$ are the blue color before and after drying, respectively,

$G L$ - the gray level of the sample and defined as average changes occurring in red, blue and green.

The specific energy consumption (SEC) for eliminating one kilogram of moisture from the mooseer samples was calculated using the follow thermodynamic equation (Amiri Chayjan et al., 2011):

$$
S E C=\left(\frac{t}{m_{v}}\right)\left[\frac{Q\left(C_{p a}+C_{p v} h_{a}\right)}{V_{h}}\right]\left(T_{i n}-T_{a m}\right)
$$

where:

$S E C$ - specific energy consumption, $\mathrm{kJ} / \mathrm{kg}$,

$C_{p v}$ - the specific heat capacity of vapor, 1004.16 $\mathrm{J} / \mathrm{kg} \cdot{ }^{\circ} \mathrm{C}$

$C_{p a}$ - the specific heat capacity of air, 1828.8 $\mathrm{J} / \mathrm{kg} \cdot{ }^{\circ} \mathrm{C}$,

$Q$ - the flow rate of input air into the drying chamber, $\mathrm{m}^{3} / \mathrm{s}$,

$t \quad$ - the total drying time, min,

$h_{a} \quad-$ absolute air humidity, $\mathrm{kg}_{\text {vapor }} / \mathrm{kg}_{\text {dry air }}$,

$T_{i n}$ and $T_{a m}$ - inlet air into the drying chamber and ambient air temperature, respectively, ${ }^{\circ} \mathrm{C}$,

$m$ - the mass of water removed, $\mathrm{kg}$,

$V_{h}-$ the specific air volume, $\mathrm{m}^{3} / \mathrm{kg}$.

It was expressed in terms of $\mathrm{MJ} / \mathrm{kg}$ of water removed and used as one of the factors in optimizing process parameters. 


\section{RESULTS AND DISCUSSION}

The results indicate that drying time is governed by the internal opposition to mass transfer due to the existence of a period of falling rates. The moisture diffusion coefficient of food and agricultural products depends on the internal conditions of the material. Table 2 shows that the $D_{\text {eff }}$ of mooseer samples was obtained in the range from $10^{-8}$ to $10^{-10} \mathrm{~m}^{2} / \mathrm{s}$. This value is higher than other agricultural crops. The drying experiments

Table 2. Central composite design and experimental data obtained for the response variables

\begin{tabular}{|c|c|c|c|c|c|c|c|c|}
\hline Experiment & $\begin{array}{c}\text { Air } \\
\text { temperature }\end{array}$ & $\begin{array}{c}\text { Air } \\
\text { velocity }\end{array}$ & $\begin{array}{c}\text { Infrared } \\
\text { power }\end{array}$ & $\begin{array}{c}\text { Slice } \\
\text { thickness }\end{array}$ & $D_{\text {eff }}$ & $S E C$ & Shrinkage & $\begin{array}{l}\text { Color } \\
\text { changes }\end{array}$ \\
\hline number & ${ }^{\circ} \mathrm{C}$ & $\mathrm{m} / \mathrm{s}$ & $\mathrm{W}$ & $\mathrm{mm}$ & $\mathrm{m}^{2} / \mathrm{s}$ & $\mathrm{MJ} / \mathrm{kg}$ & $\%$ & $\%$ \\
\hline 1 & 55 & 1.5 & 500 & 4 & $7.59 \times 10^{-10}$ & 18.22 & 43.88 & 52.30 \\
\hline 2 & 55 & 1.5 & 1000 & 4 & $1.34 \times 10^{-9}$ & 14.30 & 48.98 & 32.34 \\
\hline 3 & 40 & 2.5 & 500 & 6 & $4.99 \times 10^{-10}$ & 51.98 & 47.86 & 9.85 \\
\hline 4 & 70 & 0.5 & 1500 & 2 & $1.11 \times 10^{-9}$ & 6.98 & 34.12 & 19.9 \\
\hline 5 & 70 & 0.5 & 500 & 6 & $2.24 \times 10^{-9}$ & 5.41 & 45.92 & 39.56 \\
\hline 6 & 55 & 1.5 & 1000 & 2 & $5.46 \times 10^{-10}$ & 10.39 & 27.07 & 23.94 \\
\hline 7 & 70 & 0.5 & 1500 & 6 & $3.57 \times 10^{-9}$ & 4.49 & 50.29 & 32.95 \\
\hline 8 & 70 & 2.5 & 1500 & 2 & $8.84 \times 10^{-10}$ & 44.48 & 29.70 & 29.98 \\
\hline 9 & 40 & 0.5 & 1500 & 6 & $1.41 \times 10^{-9}$ & 8.05 & 47.69 & 22.28 \\
\hline 10 & 55 & 1.5 & 1000 & 4 & $1.04 \times 10^{-9}$ & 18.81 & 48.98 & 32.34 \\
\hline 11 & 70 & 0.5 & 500 & 2 & $8.64 \times 10^{-10}$ & 3.3 & 28.16 & 19.68 \\
\hline 12 & 55 & 1.5 & 1000 & 4 & $1 \times 10^{-9}$ & 17.43 & 48.98 & 32.34 \\
\hline 13 & 40 & 2.5 & 500 & 2 & $2.02 \times 10^{-10}$ & 15.98 & 31.1 & 14.40 \\
\hline 14 & 55 & 1.5 & 1000 & 4 & $1.16 \times 10^{-9}$ & 11.63 & 48.98 & 32.34 \\
\hline 15 & 55 & 1.5 & 1500 & 4 & $1.33 \times 10^{-9}$ & 10.41 & 47.4 & 25.64 \\
\hline 16 & 55 & 2.5 & 1000 & 4 & $9.99 \times 10^{-10}$ & 24.72 & 44.75 & 25.98 \\
\hline 17 & 40 & 2.5 & 1500 & 2 & $1.4 \times 10^{-10}$ & 29.56 & 24.79 & 5.65 \\
\hline 18 & 55 & 1.5 & 1000 & 6 & $1.54 \times 10^{-9}$ & 18.83 & 49.55 & 16.9 \\
\hline 19 & 55 & 1.5 & 1000 & 4 & $1.51 \times 10^{-9}$ & 13.22 & 48.98 & 32.34 \\
\hline 20 & 70 & 2.5 & 500 & 6 & $1.6 \times 10^{-9}$ & 32.48 & 45.67 & 31.01 \\
\hline 21 & 40 & 2.5 & 1500 & 6 & $8.13 \times 10^{-10}$ & 40.62 & 39.1 & 19.1 \\
\hline 22 & 40 & 0.5 & 500 & 6 & $7.44 \times 10^{-10}$ & 5.79 & 48.51 & 23.44 \\
\hline 23 & 70 & 1.5 & 1000 & 4 & $2.85 \times 10^{-9}$ & 8.14 & 45.49 & 41.41 \\
\hline 24 & 55 & 1.5 & 1000 & 4 & $1.34 \times 10^{-9}$ & 13.18 & 48.98 & 32.34 \\
\hline 25 & 70 & 2.5 & 1500 & 6 & $2.26 \times 10^{-9}$ & 34.05 & 45.67 & 37.1 \\
\hline 26 & 40 & 0.5 & 500 & 2 & $7.44 \times 10^{-10}$ & 7.61 & 28.47 & 10.38 \\
\hline 27 & 55 & 0.5 & 1000 & 4 & $1.32 \times 10^{-9}$ & 4.41 & 46.45 & 34.9 \\
\hline 28 & 40 & 1.5 & 1000 & 4 & $7.09 \times 10^{-10}$ & 14.43 & 42.21 & 19.55 \\
\hline 29 & 70 & 2.5 & 500 & 2 & $7.01 \times 10^{-10}$ & 14.9 & 29.41 & 31.74 \\
\hline 30 & 40 & 0.5 & 1500 & 2 & $3.94 \times 10^{-10}$ & 21.37 & 37.75 & 9.34 \\
\hline
\end{tabular}


Chayjan, R. A., Fealekari, M. (2017). Optimization of mooseer (A. hirtifolium Boiss.) dehydration under infrared conditions. Acta Sci. Pol. Technol. Aliment., 16(2), 157-170. http://dx.doi.org/10.17306/J.AFS.2017.0471

Table 3. Analysis of variance (ANOVA) for dried mooseer using a quadratic model

\begin{tabular}{|c|c|c|c|c|c|}
\hline \multirow{2}{*}{$\begin{array}{l}\text { Source of } \\
\text { variation }\end{array}$} & \multirow{2}{*}{ DoF } & \multicolumn{4}{|c|}{$F$-value } \\
\hline & & $D_{\text {eff }}$ & $S E C$ & shrinkage & color changes \\
\hline Model & 14 & $15.71 * *$ & $7.61 * *$ & $22.16^{* *}$ & $5.08 * *$ \\
\hline$X_{1}$ & 1 & $87.02 * *$ & $2.5 \mathrm{~ns}$ & $0.42 \mathrm{~ns}$ & $32.54 * *$ \\
\hline$X_{2}$ & 1 & $10.24 * *$ & $2.9 \mathrm{~ns}$ & $0.5 \mathrm{~ns}$ & $1.35 \mathrm{~ns}$ \\
\hline$X_{3}$ & 1 & $14.87 * *$ & $72.26^{* *}$ & $7.57 *$ & $0.085 \mathrm{~ns}$ \\
\hline$X_{4}$ & 1 & $66.34 * *$ & $3.28 \mathrm{~ns}$ & $197.35 * *$ & $6.58 *$ \\
\hline$X_{1} X_{2}$ & 1 & $3.09 \mathrm{~ns}$ & $0.41 \mathrm{~ns}$ & $2.94 \mathrm{~ns}$ & $0.0021 \mathrm{~ns}$ \\
\hline$X_{1} X_{3}$ & 1 & $0.43 \mathrm{~ns}$ & $0.18 \mathrm{~ns}$ & $1.31 \mathrm{~ns}$ & $1.92 \mathrm{~ns}$ \\
\hline$X_{1} X_{4}$ & 1 & $15.29 * *$ & $1.05 \mathrm{~ns}$ & $0.26 \mathrm{~ns}$ & $0.032 \mathrm{~ns}$ \\
\hline$X_{2} X_{3}$ & 1 & $0.59 \mathrm{~ns}$ & $0.35 \mathrm{~ns}$ & $11.17 * *$ & $0.3 \mathrm{~ns}$ \\
\hline$X_{2} X_{4}$ & 1 & $7.88^{*}$ & $7.91^{*}$ & $2.07 \mathrm{~ns}$ & $0.59 \mathrm{~ns}$ \\
\hline$X_{3} X_{4}$ & 1 & $2.31 \mathrm{~ns}$ & $8.07 *$ & $0.036 \mathrm{~ns}$ & $3.12 \mathrm{~ns}$ \\
\hline$X_{1}^{2}$ & 1 & $8.99 * *$ & 0.032 & $1.31 \mathrm{~ns}$ & $0.31 \mathrm{~ns}$ \\
\hline$X_{2}^{2}$ & 1 & $2.19 \mathrm{~ns}$ & $0.38 \mathrm{~ns}$ & $0.00015 \mathrm{~ns}$ & $2.74 \mathrm{~ns}$ \\
\hline$X_{3}^{2}$ & 1 & $0.6 \mathrm{~ns}$ & $0.46 \mathrm{~ns}$ & $0.0042 \mathrm{~ns}$ & $0.33 \mathrm{~ns}$ \\
\hline$X_{4}^{2}$ & 1 & $2.22 \mathrm{~ns}$ & $0.48 \mathrm{~ns}$ & $22.01 * *$ & $10.13^{* *}$ \\
\hline Residual & 15 & & & & \\
\hline Pure error & 5 & & & & \\
\hline Correlation total & 29 & & & & \\
\hline
\end{tabular}

\footnotetext{
*Significant at $5 \%$.

** Significant at $1 \%$.

ns - non significant.
}

of mooseer continued until the moisture content of the samples dropped from 1.99 (d.b.) to 0.08 (d.b.). Table 3 indicates that all four independent variables and the interaction effect of air temperature and slice thickness and the quadratic value of air temperature have a significant effect on $D_{\text {eff }}$ at a level of $1 \%$. Moreover, the interaction effect of infrared power and slice thickness on $D_{\text {eff }}$ was significant at a level of $5 \%$. Figures 1,2 and 3 show these effects. The results indicate that the effect of air temperature was more than the other independent variables. The effect of slice thickness was also greater than air velocity and infrared power. Furthermore, as the air temperature, infrared power and slice thickness increased, so did $D_{\text {eff }}$ An increase in air velocity led to a reduction in $D_{\text {eff }}$. With the higher air temperature and infrared power, the mass transfer increased and subsequently so did $D_{\text {eff }}$. This is due to an increase in the internal energy of the mooseer samples and hence a rise in the evaporation rate of moisture content.

The increase in effective moisture diffusivity was apparently due to the increased heat transfer potential between the surrounding air and the mooseer samples, as well as the higher moisture diffusivity, thus enhancing the evaporation of water from mooseer samples. These results are similar to previous studies, such as those on garlic cloves (Sharma and Prasad, 2001), 


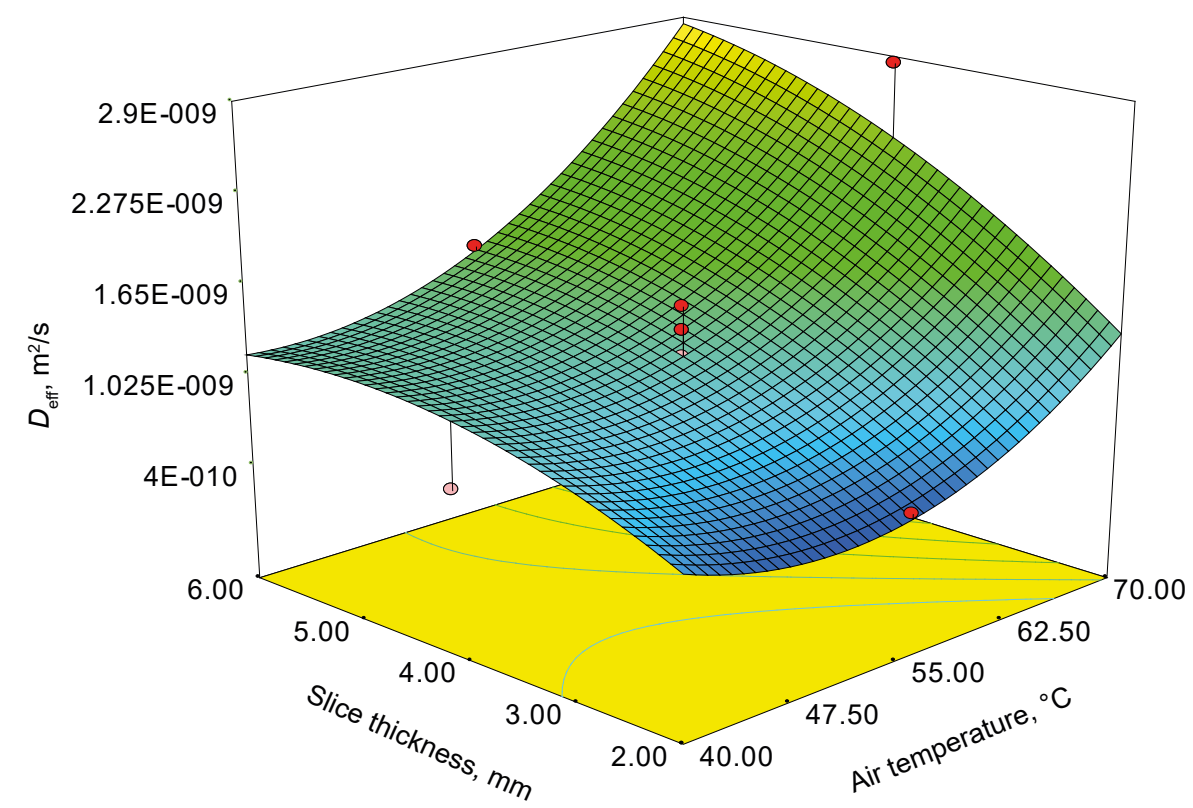

Fig. 1. The interaction effect of air temperature and slice thickness on the effective moisture diffusivity of mooseer samples

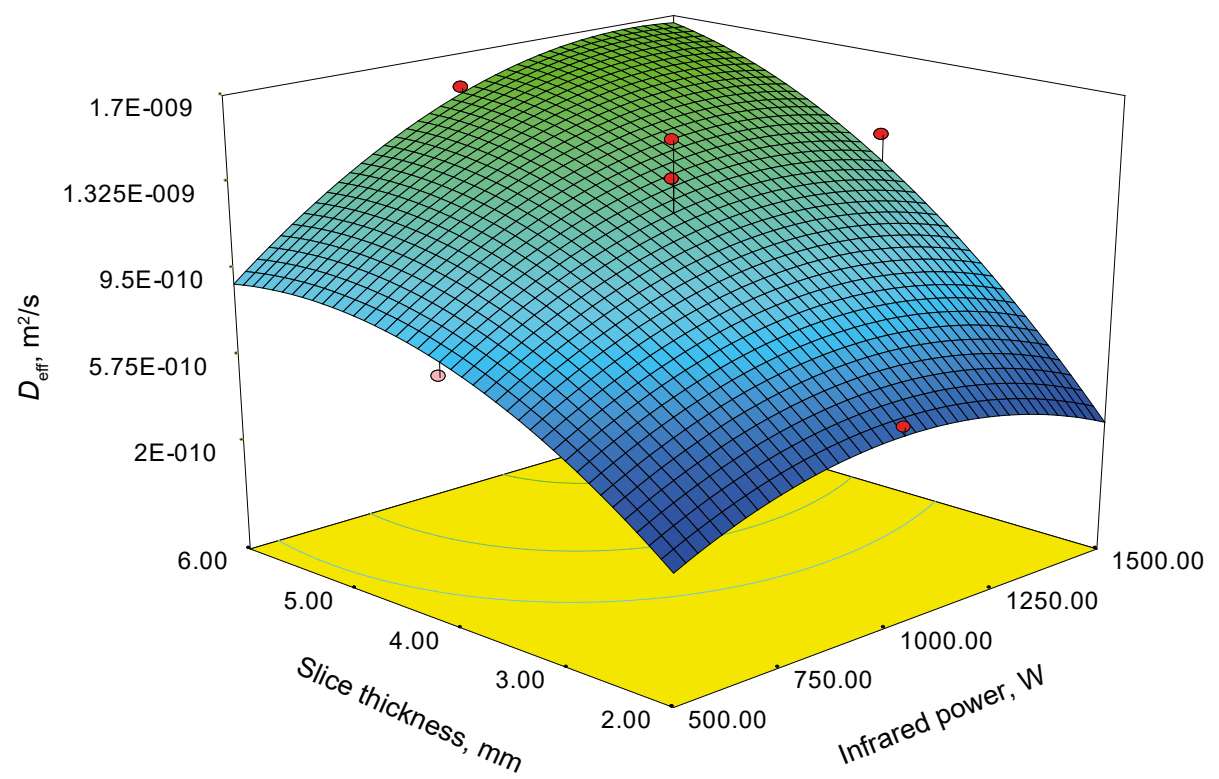

Fig. 2. The interaction effect of infrared power and slice thickness on the effective moisture diffusivity of mooseer samples 


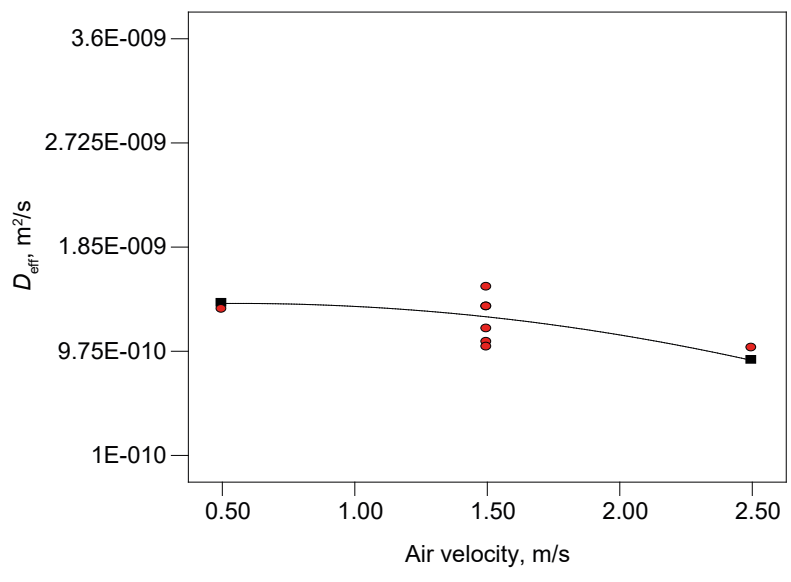

Fig. 3. The effect of air velocity on the effective moisture diffusivity of mooseer samples

berberis fruit (Aghbashlo et al., 2008), tarragon (Arabhosseini et al., 2007), and potato slices (Aghbashlo et al., 2009). Moreover, other studies found that an increase in infrared power causes an increase in $D_{\text {eff }}$ (Arslan and Özcan, 2011; Doymaz, 2011). An increase in air velocity led to a reduction in $D_{\text {eff }^{*}}$ With higher slice thickness due to greater volume of the sample, $D_{\text {eff }}$ increased. In this study the maximum value of $D_{\text {eff }}$ $\left(3.57 \times 10^{-9} \mathrm{~m}^{2} / \mathrm{s}\right)$ was calculated an at air temperature of $70^{\circ} \mathrm{C}$, an infrared power of $1500 \mathrm{~W}$, air velocity of $0.5 \mathrm{~m} / \mathrm{s}$ and slice thickness of $6 \mathrm{~mm}$. Furthermore, the minimum value of $D_{\text {eff }}\left(1.4 \times 10^{-10} \mathrm{~m}^{2} / \mathrm{s}\right)$ was achieved at an air temperature of $40^{\circ} \mathrm{C}$, infrared power of $1500 \mathrm{~W}$, air velocity of $2.5 \mathrm{~m} / \mathrm{s}$ and slice thickness of $2 \mathrm{~mm}$. Variations inf the $D_{\text {eff }}$ values were modeled as eq. (12).

$$
\begin{gathered}
D_{\text {eff }}=2.24 \times 10^{-9}-\left(2.46 \times 10^{-10}\right) T+\left(8.99 \times 10^{-13}\right) I_{r}+ \\
\left(6 \times 10^{-10}\right) v+\left(1.58 \times 10^{-10}\right) T h+\left(8.58 \times 10^{-12}\right) T \times T h+ \\
\left(1.85 \times 10^{-13}\right) I_{r} \times T h+\left(2.18 \times 10^{-12}\right) T^{2} \quad R^{2}=93.62 \%(11)
\end{gathered}
$$

where:

$$
\begin{aligned}
& T-\text { air temperature, }{ }^{\circ} \mathrm{C}, \\
& I_{r}-\text { the infrared radiation power, } \mathrm{W}, \\
& T h \text { - the mooseer slice thickness, } \mathrm{mm}, \\
& v-\text { air velocity, } \mathrm{m} / \mathrm{s} .
\end{aligned}
$$

Shrinkage of foodstuffs is a negative index in the quality of the dried products. Changes in shape, loss of volume and increased hardness cause in most cases a negative impression in the consumer (Mayor and Sereno, 2004). The slice thickness and interaction effect of air velocity with infrared power had a significant effect (at level of 1\%) on the shrinkage of mooseer samples, while air temperature and velocity had no significant effect on shrinkage (Table 3). A shrinkage study of potatoes found that air velocity had no significant effect on shrinkage (Yadollahinia and Jahangiri, 2009), while a shrinkage study of carrot slices found that air temperature and velocity had no significant effect on shrinkage either (Hatamipour and Mowla, 2002).

The effect of slice thickness on shrinkage is shown in Figure 4. The interaction effect of air velocity and slice thickness on shrinkage is shown in Figure 5. With increased the slice thickness, so shrinkage increases. In the greater slice thickness, as the temperature increases, a greater volume of water in the samples will transferred. Moreover, in this case, the drying rate of the sample increased and, consequently, shrinkage increased. Due to the higher moisture content of mooseer, in a higher volume, more water would be transferred than lower volume. There is an obvious increasing trend in the shrinkage value, while time and slice thickness increased. In actual fact, the increase in time and slice thickness increased the amount of heat given to the mooseer slices, which results in decreasing moisture content in the sample. Therefore, contractile stresses occur in the cellular structure of the mooseer samples, which intensify shrinkage. However, the shrinkage value becomes relatively constant at the end of the drying process, which is the result of

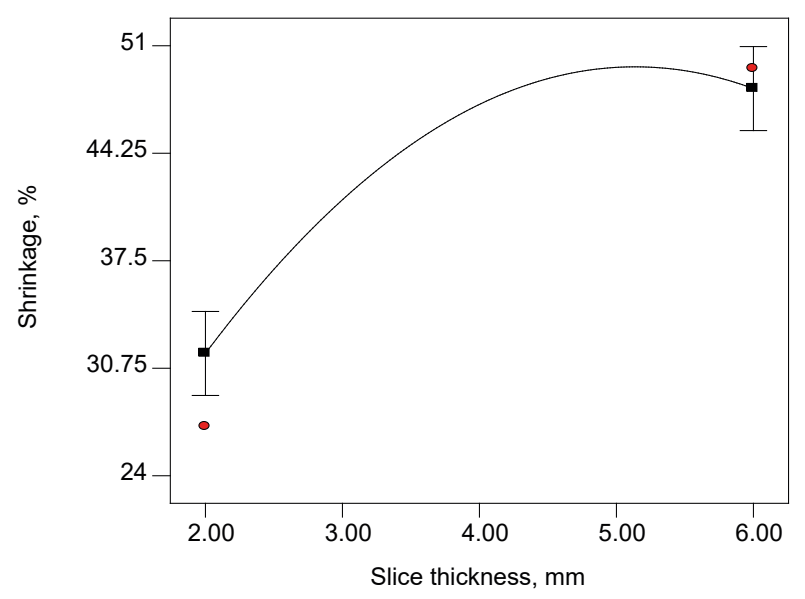

Fig. 4. The effect of slice thickness on the shrinkage of mooseer samples 


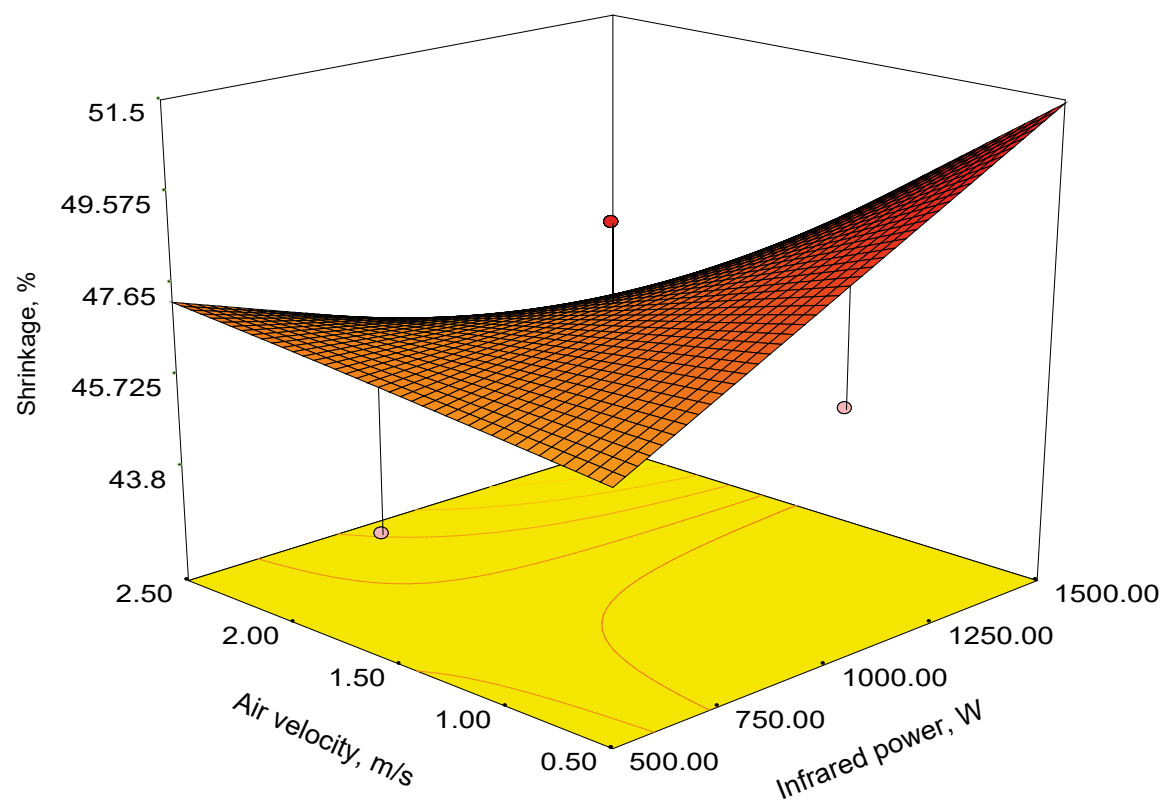

Fig. 5. The interaction effect of air velocity and infrared power on the shrinkage of mooseer samples

the sample structure stabilization resulting from a firm layer forming on its surface. Similar results were obtained in the optimization of a drying process of $\mathrm{Ca}$ vendish banana slices (Swasdisevi et al., 2007) and in shrinkage evaluation of sliced banana (Ebrahimi et al., 2012). The shrinkage value increased slightly with higher air temperature. A similar result was reported in a study on carrot shrinkage (Hatamipour and Mowla, 2002). The maximum value of shrinkage (50.29\%) was obtained at an air temperature of $70^{\circ} \mathrm{C}$, an infrared power of $1500 \mathrm{~W}$, air velocity of $0.5 \mathrm{~m} / \mathrm{s}$ and slice thickness of $6 \mathrm{~mm}$. Furthermore, minimum value of shrinkage $(24.79 \%)$ was obtained at an air temperature of $40^{\circ} \mathrm{C}$, infrared power of $1500 \mathrm{~W}$, air velocity of 2.5 $\mathrm{m} / \mathrm{s}$ and slice thickness of $2 \mathrm{~mm}$ (Table 2). The shrinkage model of the mooseer slices was as Eq. (12).

$$
\begin{gathered}
S_{b}=-25997.1+(0.1) v+(19.14) T h- \\
-\left(4.19 \times 10^{-3}\right) I_{r} \times v-(83000) T h^{2} \quad R^{2}=95.39 \%
\end{gathered}
$$

Color is considered a fundamental physical property of agriculture products and foods, since it has been widely demonstrated that it correlates well with other physical, chemical and sensorial indicators of product quality. In fact, color plays a major role in the assessment of external quality in food industries and food engineering research (Mendoza et al., 2006).

Table 2 shows the value of color changes in different experiments. Air temperature had a significant effect on color changes at a level of $1 \%$ (Fig. 6). The color changes in mooseer sample increased with as

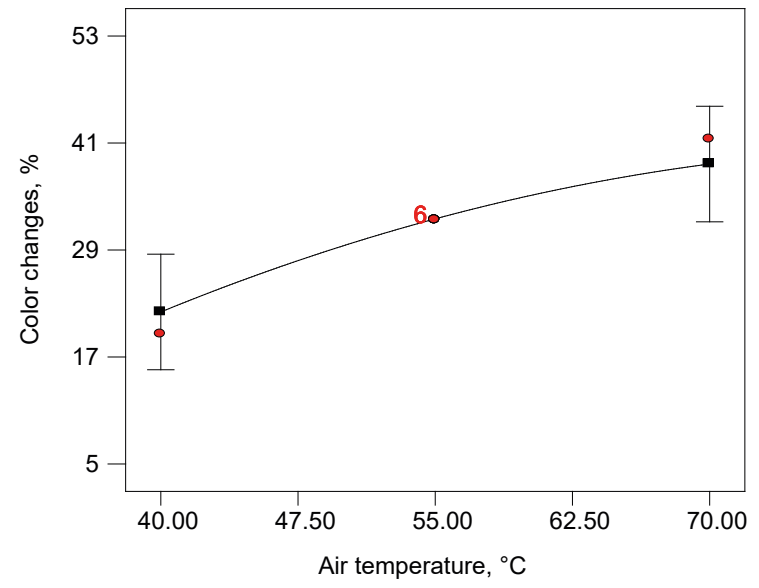

Fig. 6. The effect of air temperature on color change of mooseer samples 
air temperature rose. Inlet air velocity, infrared power and slice thickness had no significant effect on color changes. Similar results were reported in the dehydration of Kastamonu garlic slices (Sacilic and Unal, 2005), tarragon (Arabhosseini et al., 2007), banana (Swasdisevi et al., 2007) and horse mackerel (Shi et al., 2008). Color changes may be due to browning reactions which occur during the drying process (Arslan and Özcan, 2011). At high temperatures the enzymatic and non-enzymatic reaction, superficial burns and blackening of the samples ensues. Hence, in this condition, the color change increased. The maximum and minimum values of color changes were obtained at an air temperature of $55^{\circ} \mathrm{C}$, infrared power of $500 \mathrm{~W}$, air velocity of $1.5 \mathrm{~m} / \mathrm{s}$ and slice thickness of $4 \mathrm{~mm}$ $(52.3 \%)$ and at an air temperature of $40^{\circ} \mathrm{C}$, infrared power of $1500 \mathrm{~W}$, air velocity of $2.5 \mathrm{~m} / \mathrm{s}$ and slice thickness of $2 \mathrm{~mm}(5.65 \%)$. The software for describing the sample color changes presented a polynomial equation as Eq. (13).

$$
\begin{aligned}
& C=-45.49+(1.35) T+(26.63) T h- \\
& -(3.05) T h^{2} \quad R^{2}=92.58 \%
\end{aligned}
$$

where:

$$
C \text { - color change, } \% \text {. }
$$

The effect of air velocity, the interaction effect of infrared power and slice thickness (Fig. 7) and interaction effect of air velocity and slice thickness (Fig. 8) was significant on $S E C$ at a level of $1 \%$ (Table 3). Air temperature had no significant effect on $S E C$. Specific energy consumption increased with higher air velocity. Due to the reduction in water vapor in the surroundings of the samples, an increase in the drying rate and, subsequently, a decrease in drying time, the lowest energy consumption was obtained at the lowest air velocities. Moreover, due to the reduction in the contact surface of samples with hot air, the lowest energy consumption was obtained at the lowest velocities of inlet air. Similar results were reported in modeling the drying characteristics of potato slices (Amiri Chayjan, 2012) and drying of berberis fruit (Aghbashlo et al., 2008). The maximum value of $S E C(51.98 \mathrm{MJ} / \mathrm{kg})$ was obtained at an air temperature of $40^{\circ} \mathrm{C}$, infrared power of $500 \mathrm{~W}$, air velocity of $2.5 \mathrm{~m} / \mathrm{s}$ and slice thickness of $6 \mathrm{~mm}$. Furthremore, the minimum value of $S E C$

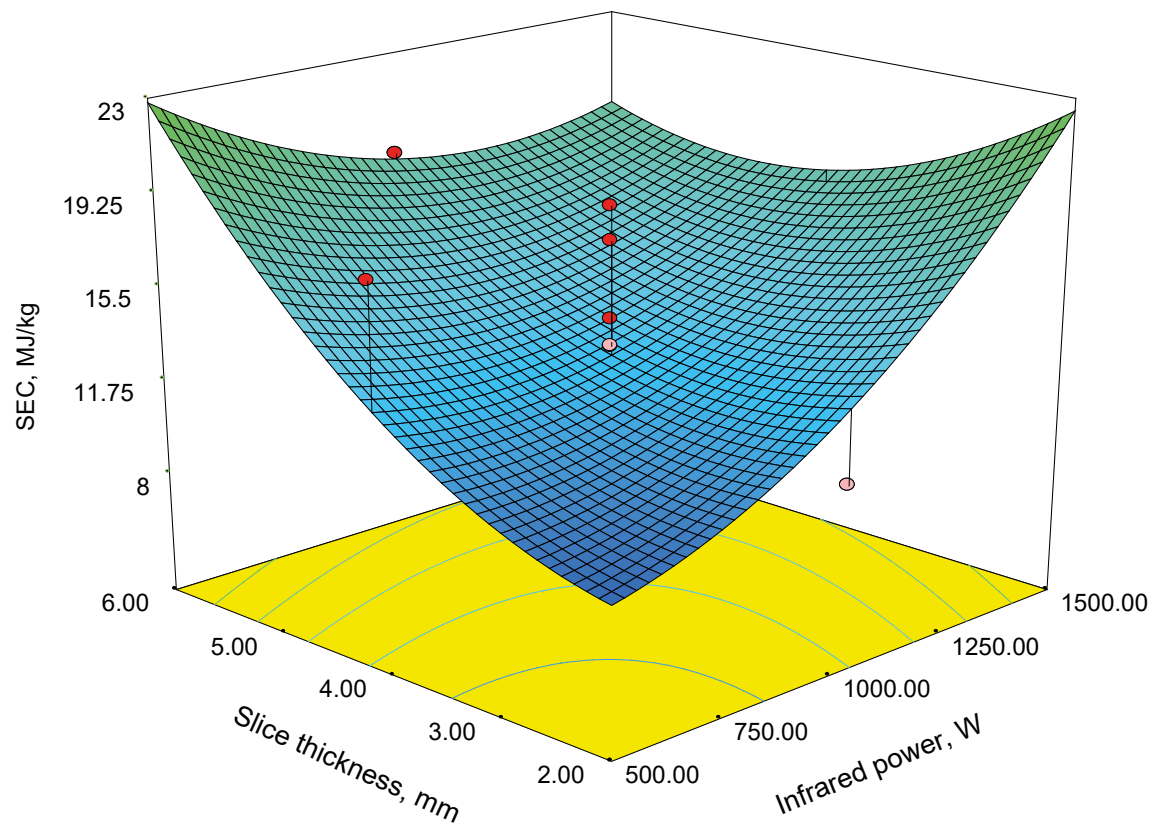

Fig. 7. The interaction effect of slice thickness and infrared power on SEC for the drying of mooseer samples 


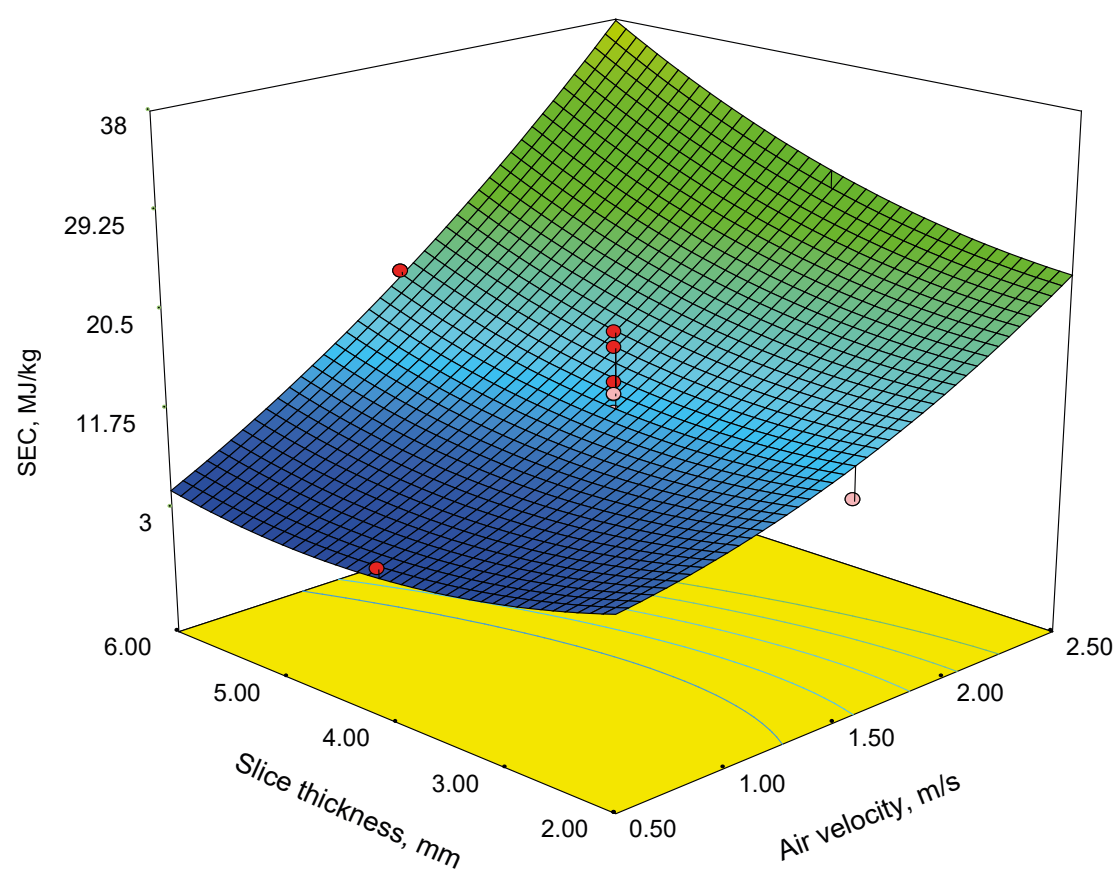

Fig. 8. The interaction effect of slice thickness and air velocity on SEC for the drying of mooseer samples

(3.3 $\mathrm{MJ} / \mathrm{kg}$ ) was obtained at an air temperature of $70^{\circ} \mathrm{C}$, infrared power of $500 \mathrm{~W}$, air velocity of $0.5 \mathrm{~m} / \mathrm{s}$ and slice thickness of $2 \mathrm{~mm}$ (Table 2). The proposed equation for $S E C$ prediction is expressed as Eq. (14).

$$
\begin{aligned}
S E C & =+7.53-(8.42) v-\left(4.31 \times 10^{-3}\right) I_{r} \times T h+ \\
& +(2.17) v \times T h \quad R^{2}=97.66 \%
\end{aligned}
$$

During the optimization of industrial processes, several response variables describing the quality characteristics and perform measures of the systems are usually optimized. Some of these variables are to be maximized, while some are to be minimized. In many cases, these responses 'compete', i.e., improving one response may have an opposite effect on another, which further complicates the situation. Several approaches have been used to deal with this problem. One approach uses a constrained optimization procedure, the second is to superimpose the contour diagrams of the different response variables, and the third approach is to solve the problem of multiple responses through the use of a desirability function combining all responses into one measurement (Erbay and Icier, 2010). The specific step of desirability function optimization includes: (1) making response variables dimensionless, (2) deciding on a weighting coefficient, (3) constituting the desirability function and solution (weighted linear method; multiplication and division method; shortest distance ideal point method) and (4) optimizing by the preferred method (Shi et al., 2008).

Optimum conditions for convective-infrared drying of mooseer were calculated to obtain the maximum $D_{\text {eff }}$ and minimum level of shrinkage, color changes and SEC. In this study, second order polynomial models obtained were utilized for each response in order to determine the specified optimum conditions. These regression models for each response are valid only in the experimental domain selected. Thus, the operating region was determined by considering some economic and product quality-related constraints.

In this study, air temperature, infrared power, air velocity and slice thickness were selected in the range of $40-70^{\circ} \mathrm{C}, 500-1500 \mathrm{~W}, 0.5-2.5 \mathrm{~m} / \mathrm{s}$, and $2-6 \mathrm{~mm}$, respectively. The solutions were proposed for the optimum covering the criteria by applying the desirability function method. This was $70^{\circ} \mathrm{C}$ for air temperature, $867.46 \mathrm{~W}$ for infrared power, $0.59 \mathrm{~m} / \mathrm{s}$ for air velocity 
Chayjan, R. A., Fealekari, M. (2017). Optimization of mooseer (A. hirtifolium Boiss.) dehydration under infrared conditions. Acta Sci. Pol. Technol. Aliment., 16(2), 157-170. http://dx.doi.org/10.17306/J.AFS.2017.0471

Table 4. Optimal conditions for applying desirability functions methodology

\begin{tabular}{cccccccccc}
\hline $\begin{array}{c}\text { Solution } \\
\text { number }\end{array}$ & $\begin{array}{c}\text { Desirability } \\
\text { temperature } \\
{ }^{\circ} \mathrm{C}\end{array}$ & $\begin{array}{c}\text { Infrared } \\
\text { power } \\
\mathrm{W}\end{array}$ & $\begin{array}{c}\text { Slice } \\
\text { thickness } \\
\mathrm{mm}\end{array}$ & $\begin{array}{c}\text { Air } \\
\text { velocity } \\
\mathrm{m} / \mathrm{s}\end{array}$ & $\begin{array}{c}\text { Color } \\
\text { changes } \\
\%\end{array}$ & $\begin{array}{c}\text { Shrinkage } \\
\%\end{array}$ & $\begin{array}{c}S E C \\
\mathrm{MJ} / \mathrm{kg}\end{array}$ & $\begin{array}{c}\mathrm{D}_{\text {eff }} \\
\mathrm{m}^{2} / \mathrm{s}\end{array}$ \\
\hline 1 & 0.689 & 70 & 867.46 & 2 & 0.59 & 17.62 & 29.58 & 4.64 & $1.32 \times 10^{-9}$ \\
2 & 0.689 & 70 & 1038.76 & 2 & 0.5 & 15.58 & 31.14 & 5.56 & $1.39 \times 10^{-9}$ \\
3 & 0.688 & 70 & 1050.26 & 2 & 0.5 & 15.55 & 31.29 & 6.69 & $1.4 \times 10^{-9}$ \\
4 & 0.686 & 70 & 772.29 & 2 & 0.5 & 18.85 & 28.75 & 3.38 & $1.25 \times 10^{-9}$ \\
5 & 0.683 & 70 & 744.98 & 2 & 0.5 & 19.37 & 28.5 & 3.12 & $1.29 \times 10^{-9}$ \\
6 & 0.676 & 70 & 802.6 & 2 & 0.75 & 20.27 & 29.02 & 4.6 & $1.28 \times 10^{-9}$ \\
\hline
\end{tabular}

and $2 \mathrm{~mm}$ for slice thickness. At this point, $D_{\text {eff }}, S E C$, shrinkage and color changes were determined as $1.32 \times 10^{-9} \mathrm{~m}^{2} / \mathrm{s}, 4.64 \mathrm{MJ} / \mathrm{kg}, 29.58 \%$ and $17.62 \%$, respectively. By applying the desirability function method, six solutions were proposed for the optimum covering criteria (Table 4). The optimal values for the factors considered can be one of six solutions, since the value of the desired function is a unit with a desirability value of 0.689 . The final decision of the optimal conditions depends on considerations of costs and effects in the sensory characteristics of the product.

\section{CONCLUSIONS}

In this study, some physical and thermal properties of mooseer were investigated in a laboratory infraredconvective dryer to determine the $D_{\text {eff }}, S E C$, shrinkage and color changes, at air temperature levels of 40 , 55 and $70^{\circ} \mathrm{C}$, infrared power of 500,100 and $1500 \mathrm{~W}$, air velocity levels of $0.5,1.5$ and $2.5 \mathrm{~m} / \mathrm{s}$ and slice thicknesses of 2, 4, and $6 \mathrm{~mm}$. The $R S M$ method was used to determine the optimum operating conditions that yield the maximum value of $D_{\text {eff }}$ and minimum values of shrinkage, color change and specific energy consumption $(S E C)$ in infrared-convective drying of mooseer. As air temperature and slice thickness increased, $D_{\text {eff }}$ increased. Shrinkage increased with greater slice thickness. The air temperature had a significant effect on color changes. Higher air velocity led to an increase in $S E C$. The central composite design $(C C D)$ was used to optimize the process. The optimal conditions for maximum $D_{\text {eff }}$ and minimum shrinkage, color changes and SEC correspond to a temperature of $70^{\circ} \mathrm{C}$, infrared power of $867.46 \mathrm{~W}$, air velocity of $0.59 \mathrm{~m} / \mathrm{s}$, and slice thickness of $2 \mathrm{~mm}$ in order to obtain $D_{\text {eff }}$ of $1.32 \times 10^{-9} \mathrm{~m}^{2} / \mathrm{s}$, a shrinkage of $29.58 \%$, color changes of $17.62 \%$ and $S E C$ of 4.64 $\mathrm{MJ} / \mathrm{kg}$. The desirability value of 0.689 was obtained for the drying process.

\section{REFERENCES}

Abbasi Surki, A., Sharifzade, F., Tavakkol Afshari, R., Majnoun Hosseini, N., Gazor, H. R. (2010). Optimization of processing parameters of soybean seeds dried in a constant-bed dryer using response surface methodology. J. Agric. Sci. Technol., 12, 409-423.

Aghbashlo, M., Kianmehr, M. H., Samimi-Akhijahani H. (2008). Influence of drying conditions on the effective moisture diffusivity, energy of activation and energy consumption during the thin-layer drying of beriberi fruit (Berberidaceae). Energy Conv. Manag., 49, 2865-2871.

Aghbashlo, M., Kianmehr, M. H., Rabhosseini, A. (2009). Modeling of thin-layer drying of potato slices in length of continuous band dryer. Energy Conv. Manag., 50, 1348-1355. http://dx.doi.org/10.1016/j. enconman.2009.01.004

Amiri Chayjan, R., Peyman, M. H., Esna-Ashari, M., Salari, K. (2011). Influence of drying conditions on diffusivity, energy and color of seedless grape after dipping process. Aust. J. Crop Sci., 5, 96-103.

Amiri Chayjan, R. (2012). Modeling some drying characteristics of high moisture potato slices in fixed, semi fluidized and fluidized bed conditions. J. Agric. Sci. Technol., 14, 1229-1241. 
Amouzgar, P., Abdul Khalil, H. P. S., Salamatinia, B., Zuhairi Abdullah, A., Essam, A. M. (2010). Optimization of bioresource material from oil palm trunk core drying using microwave radiation; a response surface methodology application. J. Biores. Technol., 101, 8396-8401. http://dx.doi.org/10.1016/j.biortech.2010.05.061

Arabhosseini, A., Huisman, W., Van Boxtel, A., Muller, J. (2007). Long-term effects of drying conditions on the essential oil and color of tarragon leaves during storage. J. Food Eng., 79, 561-566. http://dx.doi.org/10.1016/j. jfoodeng.2006.02.014

Arslan, D., Özcan, M. M. (2011). Dehydration of red bell-pepper (Capsicum annuum L.): Change in drying behavior, colour and antioxidant content. Food Bioprod. Proc., 89, 504-513. http://dx.doi.org/10.1016/j. fbp.2010.09.009

ASAE, (1996). ASAE standards: moisture measurementunground grains and seeds. St. Joseph, MI: American Society of Agricultural Engineers.

Corzo, O., Bracho, N., Va'squez, A., Pereira, A. (2008). Optimization of a thin layer drying process for coroba slices. J. Food Eng., 85, 372-380. http://dx.doi.org/10.1016/j. jfoodeng.2007.07.024

Crank, J. (1975). Mathematics of diffusion. London: Oxford University Press.

Doymaz, I. (2011). Infrared drying of sweet potato (Ipomoea batatas L.) slices. J. Food Sci. Technol., 49(6), 760-766. http://dx.doi.org/10.1007/s13197-010-0217-8

Ebrahimi, M. A., Mohtasebi, S. S., Rafieem, S., Hosseinpour, S. (2012). Investigation of banana slices shrinkage using image processing technique. Aust. J. Crop Sci., 6(5), 938-945.

Ebrahimi, R., Zamani, Z., Kashi, A. (2009). Genetic diversity evaluation of wild Persian shallot (Allium hirtifolium Boiss.) using morphological and RAPD markers. Sci Hort., 119, 345-435. http://dx.doi.org/10.1016/j. scienta.2008.08.032

Eidi, A., Eidi, M., Esmaeili, E. (2006). Antidiabetic effect of garlic (Allium sativum L.) in normal and streptozotocininduced diabetic rats. Phytomedicine, 13(9-10), 624629. http://dx.doi.org/10.1016/j.phymed.2005.09.010

Erbay, Z., Icier, F. (2010). A review of thin layer drying of foods: theory, modeling, and experimental results. Crit. Rev. Food Sci. Nut., 50, 441-464. http://dx.doi. org/10.1080/10408390802437063

Eren, I., Kaymak-Ertekin, F. (2007). Optimization of osmotic dehydration of potato using response surface methodology. J. Food Eng., 79, 344-352. http://dx.doi. org/10.1016/j.jfoodeng.2006.01.069
Ghahreman, A. (1984). Color Atlas of Iranian Plants. Institute of Forestries and Grasslands, Botany Division 5.

Hatamipour, M. S., Mowla, D. (2002). Shrinkage of carrots during drying in an inert medium fluidized bed. J. Food Eng., 55, 247-252. http://doi.org/10.1016/S0260-8774 (02)00082-1

Jain, D., Pathare, P. B. (2007). Study the drying kinetics of open sun drying of fish. J. Food Eng., 78, 1315-1319. http://dx.doi.org/10.1016/j.jfoodeng.2005.12.044

Kiat Pua, C. A., Hamid, N. S., Chin, P. T., Mirhosseini, H. A., Rahman, R. B., Rusul, G. (2010). Optimization of drum drying processing parameters for production of jackfruit (Artocarpusheter ophyllus) powder using response surface methodology. LWT - Food Sci. Technol., 43, 343349. http://dx.doi.org/10.1016/j.lwt.2009.08.011

Mendoza, F., Dejmek, P., Aguilera J. M. (2006). Calibrated color measurements of agricultural foods using image analysis. Postharv. Biol. Technol., 41, 285-295.

Mayor, L., Sereno, A. M. (2004). Modeling shrinkage during convective drying of food material: a review. J. Food Eng., 18, 373-386. http://dx.doi.org/10.1016/ S0260-8774(03)00144-4

Montgomery, D. C. (2001). Design and analysis of experiments. New York: John Wiley.

Nazghelichi, T., Aghbashlo, M., Kianmehr, M. H. (2011). Optimization of an artificial neural network topology using coupled response surface methodology and genetic algorithm for fluidized bed drying. Comp. Elect. Agric., 75, 84-91. http://dx.doi.org/10.1016/j.compag.2010.09.014

Omid, M., Baharlooei, A., Ahmadi, H. (2009). Modeling drying kinetics of pistachio nuts with multilayer feedforward neural network. Drying Technol., 10, 10691077. http://dx.doi.org/10.1080/07373930903218602

Sacilic, K., Unal, G. (2005). Dehydration characteristics of Kastamonu garlic slices. J. Biosyst. Eng., 92, 207-215. http://dx.doi.org/10.1016/j.biosystemseng.2005.06.006

Sharma, G. P., Prasad, S. (2001). Drying of garlic (Allium sativum) cloves by microwave-hot air combination. J. Food Eng., 50, 99-105. http://dx.doi.org/10.1016/ S0260-8774(00)00200-4

Sharma, G. P., Prasad, P. (2006). Optimization of process parameters for microwave drying of garlic cloves. J. Food Eng., 75, 441- 446. http://dx.doi.org/10.1016/j. jfoodeng.2005.04.029

Shi, Q. L., Xue, C. H., Zhao, Y., Li, Z. J., Wang, X. Y., Luan, D. L. (2008). Optimization of processing parameters of horse mackerel (Trachurus japonicus) dried in a heat pump dehumidifier using response surface methodology. J. Food Eng., 87, 74-81. http://dx.doi.org/10.1016/j. jfoodeng.2007.11.010 
Swasdisevi, T., Devahastin, S., Ngamchum, R., Soponronnarit, S. (2007). Optimization of a drying process using infrared-vacuum drying of Cavendish banana slices. J. Sci. Technol., 29(3), 809-816.

Togrul, H. (2005). Simple modeling of infrared drying of fresh apple slices. J. Food Eng., 71, 311-323. http:// dx.doi.org/10.1016/j.jfoodeng.2005.03.031

Varnalis, A. I., Brennan, J. G., MacDougall, D. B., Gilmour, S. G. (2004). Optimization of high temperature puffing of potato cubes using response surface methodology.
J. Food Eng., 61, 153-163. http://dx.doi.org/10.1016/ S0260-8774(03)00082-7

Wani, A. A., Kaur, D., Ahmed, I., Sogi, D. S. (2008). Extraction optimization of watermelon seed protein using response surface methodology. J. Food Sci. Technol., 41, 1514-1520. http://dx.doi.org/10.1016/j.lwt.2007.10.001 Yadollahinia, A., Jahangiri, M. (2009). Shrinkage of potato slices during drying. J. Food Eng. 94, 52-58. http:// dx.doi.org/10.1016/j.jfoodeng.2009.02.028 